African Journal of Educational Studies in Mathematics and Sciences Vol. 15, No. 2. 2019

\title{
Teachers' role and learners' responsibility in teaching and learning science and elementary technology in Rwanda
}

\author{
J.C Nzeyimana ${ }^{1} \&$ K. Ndihokubwayo ${ }^{2}$
}

\begin{abstract}
The aim of the present study is to reveal teachers' role in teaching and learners' responsibility in learning Science and Elementary Technology in Rwanda. The source of information is the classroom observation (Upper Primary) from 6 schools purposively selected in Kayonza District. The Flanders Interaction Analysis Categories System analysis research tools revealed that: The instructors' role in the learning was found information giver. Teachers had low facilitation to learning and were deciding alone on the content to be taught; concerning the learners' responsibility and their encouragement for learning, it was found that the results are far from the expectations related to a learner-centred situation: low pupils' participation, lacking initiatives from pupils and teachers not motivating/encouraging them. The learners were found passive in the classroom interaction, and only responding to teachers' questions. From the above findings, we affirm that the "teacher-centred approach" dominates in the science classrooms in Rwanda.
\end{abstract}

Keywords: $\quad$ teachers' role; students' responsibility; Flander's interaction analysis categories system

\section{Introduction}

The 2010 Rwandan "Science and Elementary Technology (SET)" curriculum for Upper Primary proposed teachers to use "a learner-centred approach where the Problem-Based Learning approach through an experimental process is the guideline for the didactic exploitation of learning". In the Rwandan national policies, the objectives of education were adopted as: "to transform the Rwandan citizen into skilled human capital for socio-economic development of the country by ensuring equitable access to quality education focusing on combating illiteracy, promotion of science and technology, critical thinking and positive values", (Ministry of Education, 2010a). Considering the science education, the Ministry in the President's Office in Charge of Science, Technology and Scientific Research in Rwanda (2006) gives clear strategies to be taken in consideration, a high focus on primary science education: "The strategy at Primary level includes the provision of a Science Corner in every Primary School to cultivate the interest in mathematics, science, and technology at an early age and help provide good grounding in scientific thinking. It shall also require a review and implementation of improved teaching methods for primary science".

\footnotetext{
${ }^{1}$ Jean Claude Nzeyimana, Med and Ag. Director of Science Inspection Unit, Basic Education Quality Assurance Department, Ministry of Education, P.O. Box 622 Kigali, Rwanda: E-mail: jcnzeyimana@mineduc.gov.rw

${ }^{2}$ Kizito Ndihokubwayo is a PhD student in Science Education at the African Centre of Excellence for Innovative Teaching/Learning Mathematics and Science (ACEITLMS), University of Rwanda-College of Education, Kigali, Rwanda. Email: ndihokubwayokizito@gmail.com
}

Open Access article distributed under the terms of the Creative Commons Attributions License [CC BY-NC-ND 4.0] http://creativecommons.org/licenses/by-nc-nd/4.0. DOI: https://dx.doi.org/10.4314/ajesms.v15i2.1 
Teachers' role and learners' responsibility in teaching and learning science and elementary technology in Rwanda

\section{J.C Nzeyimana \& K. Ndihokubwayo}

The SET subject is taught from primary four $\left(\mathrm{P}_{4}\right)$ to primary six $\left(\mathrm{P}_{6}\right)$, and contains some subjects extracted from natural sciences, physics, environmental education and home economics [Rwanda Education Board (2012) \& Ministry of Primary and Secondary Education (1996)]. According to Earnest (2006), the Ministry of Education in Rwanda implemented a new curriculum for the primary and secondary schools in September 1998. In 2010, the Rwanda Education Board (REB), an institution affiliated to the Ministry of Education has revised the SET curriculum. The main reasons that directed to that revision were: "(1) Exclusion of SET subject lessons in lower primary $\left(\mathrm{P}_{1}-\mathrm{P}_{3}\right)$ and (2) the need to introduce new and better teaching methods: Problem-Based Learning (approach that allows learners to be architects of their own learning)" (Rwanda Education Board, 2012) while in the previous curriculum, the suggested teaching approach was just "learner-centred approach" (Rwanda Education Board, 2012).

Nowadays, the nature of teaching leads to a question in education concerning the role of the teacher. Should teachers directly instruct their learners? Or is the teacher's role simply to encourage and support learners as they learn and construct knowledge for themselves? The two questions are related to two different concepts: teacher-centred and learner-centred teaching approaches [Jarvis (2006), Westwood (2008)]. The two contrasting teaching approaches started with two philosophical ideas, the Instructivist and Constructivist perspectives. These two lines are respectively referred to the current professional literature as on one hand, "traditional didactic teaching", "teacher-focused instruction" or "explicit instruction" and on the other hand, "progressive methods", "learner-focused instruction" or "minimally guided instruction" (Trigwell, 2006; and Adkisson \& McCoy, 2006; quoted by Westwood, 2008).

According to Ertmer \& Simons (2006) and Savery (2006), the challenge for many instructors when they adopt student-centred teaching approach is to make the transition from the teacher as knowledge provider to tutor as manager and facilitator of learning.

In teacher-centred approach, the teacher's role is information giver and directing the learning, he/she acts as a gatekeeper of knowledge, controlling learners ' access to information, dispense accurate knowledge; set learning goal, and check learners' knowledge by searching predetermined response. The teacher determines what to teach and how to teach as a dictator. Therefore, learners' encouragement tends to take the form of competition between themselves largely based on grades, passively receive information, listening to the explanation from teachers, they raise questions occasionally, simply reconstruct knowledge and information without necessarily understanding it. Their focus is mainly note-taking, and memorising information for later recognition or reproduction (learning until mastery). Teaching is geared for the 'average' learner and every learner is forced to progress at the same rate (Kolb, 1981; Huba \& Freed, 2000; Anderson et al., 2001; Weimer, 2002; Di Napoli, 2004; Allen, 2004; Kisangi, 2006; Westwood, 2008; Attard, Di Ioio, Geven, \& Santa, 2010 and Siddiquee \& Ikeda, 2013b).

In learner-centred approach, the teacher's role is to guide, coach, and facilitate learning; teachers help learners to develop their own inquiry, listen carefully to learners' interpretation of data, paying particular attention to any individual's conundrums, puzzlements, confusions; learners guided towards concrete experience, reflective observation, abstract conceptualization and active experimentation in their learning; their ideas (correct or incorrect) are always respected. Thus, the learners have an intrinsic encouragement for learning, with the emphasis on cooperation, rather 
than competition and are actively involved in their learning. Learners are creators of knowledge as an autonomous explorer and are invited by teachers to take initiative; they work individually at times but often also need to collaborate in small groups, under the teacher's supervision; and work at stations with access to multiple resources; as well as self-directed learning (Kolb, 1981; Huba \& Freed, 2000; Anderson et al., 2001; Weimer, 2002; Di Napoli, 2004; Allen, 2004; Kisangi, 2006; Westwood, 2008; Attard, Di Ioio, Geven, \& Santa, 2010 and Siddiquee \& Ikeda, 2013b).

The present study aims to determine the characteristics of teaching approaches used in teaching "Science and Elementary Technology" lessons in Primary Schools of Kayonza District in Rwanda, by analysing the actual science teaching in normal primary school classrooms through videotaped lessons. In order to achieve that objective, 2 research questions will guide this study: (1) What is the teacher's role in learning activities? (2) What are the learners' responsibility and their encouragement for learning?

\section{Research Methodology}

In order to achieve the objective of the study, the researchers have visited schools and observed lessons while recording videos in primary schools in Kayonza District.

\section{Sampling and data collection}

Kayonza District is one of the eight districts of Eastern province and has been chosen to be the target of the present research for a simple reason that some primary teachers in this District are fluent in English. We have selected the 14 best performing primary schools in the 2012 National Examinations where 27 lessons were observed and videotaped, however, six of them were analysed. Teachers were asked to do nothing special beyond their daily practices for the videotape session, and asked to conduct the class as they had planned: each teacher was given the opportunity to choose by his/her own topic and teaching time.

\section{Classroom observation analysis}

Many of the observation instruments have some elements in common although they differ on various conceptual and contextual dimensions (Kisangi, 2006). According to Robert F. Bales (1999), ten to twenty different events might occur within a single minute of discussion in a classroom. Considering the Flanders' work (Flanders, 1970), "the classroom interaction analysis refers to many systems of coding spontaneous verbal communication, arranging the data into a useful display and then analysing the results in order to study patterns of teaching and learning". For him, ten categories of verbal interactions are observable in a classroom (Table 1) and the observer has to record what is happening every three seconds. The present study has used the Flanders' interaction analysis, which is found to be widely used by many researchers in the world. 
Teachers' role and learners' responsibility in teaching and learning science and elementary technology in Rwanda

J.C Nzeyimana \& K. Ndihokubwayo

Table 1: $\quad$ Flanders' Interaction Analysis Categories* (FIAC).

\begin{tabular}{|c|c|c|}
\hline $\begin{array}{l}\text { Teaching } \\
\text { move }\end{array}$ & $\begin{array}{l}\text { Type of } \\
\text { move }\end{array}$ & Description of nature of communication in interaction \\
\hline \multirow[t]{7}{*}{$\begin{array}{l}\text { Teacher } \\
\text { Talk }\end{array}$} & \multirow[t]{4}{*}{ Response } & $\begin{array}{l}\text { 1. Accepts Feeling: Accepts and clarifies the feeling tone of pupils in a non- } \\
\text { threatening manner. Feelings may be positive or negative. Predicting or } \\
\text { recalling feelings are included. }\end{array}$ \\
\hline & & $\begin{array}{l}\text { 2. Praises or Encourages: Praises or encourages pupils' action or } \\
\text { behaviour. Jokes that release tension, but not at the expense of } \\
\text { another individual; nodding head, saying "um hm?" or "go on" are } \\
\text { included. }\end{array}$ \\
\hline & & $\begin{array}{l}\text { 3. Accepts or Uses ideas: Clarifying, building, or developing ideas } \\
\text { suggested by a pupil. Teacher extensions of pupils' ideas are included } \\
\text { but as a teacher brings more of his own ideas into play, shift to category } \\
\text { five. }\end{array}$ \\
\hline & & $\begin{array}{l}\text { 4. Asks Questions: Asking a question about content or procedure with the } \\
\text { intent that a pupil answers. }\end{array}$ \\
\hline & \multirow[t]{3}{*}{ Initiation } & $\begin{array}{l}\text { 1. Lecturing: Giving facts or opinions about content or procedures; } \\
\text { expressing the teacher's own ideas, asking rhetorical questions. }\end{array}$ \\
\hline & & $\begin{array}{l}\text { 2. Giving Directions: Giving directions, commands, or orders with which a } \\
\text { pupil is expected to comply. }\end{array}$ \\
\hline & & $\begin{array}{l}\text { 3. Criticizing or Justifying Authority: Statements intended to change pupils } \\
\text { behaviour from non-acceptable to acceptable pattern; bawling } \\
\text { someone out; stating why the teacher is doing what he is doing; } \\
\text { extreme self-reference. }\end{array}$ \\
\hline
\end{tabular}

Pupil Talk Response 1. Pupil Talk-Response: Talk by pupils in response to the teacher. Teacher initiates the contact or solicits pupil statement.

Initiation 2. Pupil Talk - Initiation: Talk by pupils, which they initiate. If "calling on" pupil is only to indicate who may talk next, the observer must decide whether pupil wanted to talk. If he/she did, use this category.

Silence or Confusion 3. Silence or Confusion: Pauses, short periods of silence, and periods of confusion in which communication cannot be understood by the observer.

*Source: (Flanders, 1970)

Research tools and analysis procedure and The Flanders Interaction Analysis Categories System - FIACS

The videotaped SET lessons were analysed attempting to categorize all the verbal behaviour to be found in the classroom and classified according to the three main categories: teacher talk, pupils 
talk and silence or confusion. Flanders Interaction Analysis Categories System - FIACS (which mainly explain the teacher's activities in the lesson) was used. The FIACS system has been developed by Flanders and his colleagues at the University of Minnesota, U.S.A. between 1955 and 1960. It consists on a classification of verbal behaviour into 10 categories, under three main sections: the first seven categories include teacher talk, the next two categories include pupil talk and the last tenth category includes the small spans of silence or pause or confusion (Table 1).

Interaction analysis is a system for observing and coding the verbal interchange between a teacher and his pupils which is used to study spontaneous teaching behaviour and to help teachers modify their behaviour (Flanders, 1970). The FIACS is used to determine whether a teacher is indirect or direct in his approach to encouragement and control in the classroom. The system describes, rather than evaluates, teacher behaviours in the order in which they occur, in any subject at any level. It does not, however, include non-verbal behaviours and learner-learner interaction (Evans, 1970). It is an objective and reliable method for observation of classroom teaching. In addition to that, Evans (1970) have discussed based on literature review, that the FIACS was effective for investigating the teaching style, but does not provide a clear relationship between teaching style and teacher effectiveness.

\section{Procedure of Flanders' Interaction Analysis}

The Flanders system is composed of ten categories (Table 1) and it involves the categorization of verbal classroom interaction into ten categories by a trained observer. The observer may directly observe the classroom, or he/she may analyse audio recordings, video recordings, or tape' scripts of the classroom interaction. At the end of each three-second interval, the observer records the category number which best represents the events just completed.

In the FIACS, recording verbal behaviour is not enough. The ratios are: Teacher Talk Ratio (TT), Pupil's Talk Ratio (PT), Silence or Confusion Ratio (SC), Direct Teacher Talk Ratio (DTT) also called “Teacher Talk Initiation”, Direct Pupil Talk Ratio (DPT) also called "Pupil Talk Initiation", Indirect Teacher Talk Ratio (ITT) also called "Teacher Talk Response", Indirect Student Talk Ratio (IPT) also called "Pupil Talk Response", Indirect and Direct Ratio (ID) and Teacher's Question Ratio (TQ).

Table 2: $\quad$ Interpretation and criteria of Flanders' Interaction Analysis

\begin{tabular}{|c|c|c|c|}
\hline $\mathbf{S} / \mathbf{N}$ & Ratio & Description & Formula \\
\hline 1 & $T T$ & $\begin{array}{l}\text { The TT Ratio indicates how much } \\
\text { the teacher talks in the classroom. } \\
\text { For an ideal lesson, TT ratio } \\
\text { should be slightly equal to } P T \\
\text { ratio. }\end{array}$ & 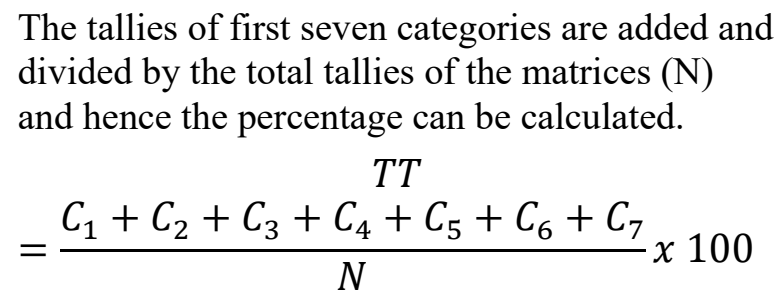 \\
\hline 2 & $P T$ & $\begin{array}{l}\text { The PT Ratio indicates verbal } \\
\text { activities of pupils in response to } \\
\text { the teacher. } \\
\text { For an ideal lesson, PT ratio } \\
\text { should be slightly equal to TT } \\
\text { ratio. }\end{array}$ & $\begin{array}{l}\text { The tallies of } 8^{\text {th }} \text { and } 9^{\text {th }} \text { categories are added and } \\
\text { divided by "N" to calculate the percentage. } \\
P T=\frac{c_{8}+c_{9}}{N} \times 100\end{array}$ \\
\hline
\end{tabular}


Teachers' role and learners' responsibility in teaching and learning science and elementary technology in Rwanda

J.C Nzeyimana \& K. Ndihokubwayo

\begin{tabular}{|c|c|c|c|}
\hline $\mathbf{S} / \mathbf{N}$ & Ratio & Description & Formula \\
\hline 3 & $S C$ & $\begin{array}{l}\text { The SC Ratio indicates how much } \\
\text { time pauses, short periods of } \\
\text { silence, and periods of confusion } \\
\text { are observed. } \\
\text { For an ideal lesson, SC ratio } \\
\text { should be very low compared to } \\
\text { TT or PT ratios. }\end{array}$ & $\begin{array}{l}\text { The tallies of } 10^{\text {th }} \text { categories are divided by "N" } \\
\text { to calculate the percentage. } \\
S C=\frac{C_{10}}{N} \times 100\end{array}$ \\
\hline 4 & $D T T$ & $\begin{array}{l}\text { The DTT indicates the teacher's } \\
\text { actions restricting pupils' } \\
\text { participation. } \\
\text { For an ideal lesson, DTT ratio } \\
\text { should be slightly equal to ITT } \\
\text { ratio. }\end{array}$ & $\begin{array}{l}\text { The tallies of } 5^{\text {th }}, 6^{\text {th }} \text { and } 7^{\text {th }} \text { categories are added } \\
\text { and divided by "N" to calculate the percentage. } \\
\text { DTT }=\frac{c_{5}+c_{6}+c_{7}}{N} \times 100\end{array}$ \\
\hline 5 & $I T T$ & $\begin{array}{l}\text { ITT Ratio indicates how much the } \\
\text { teachers respond to students' ideas } \\
\text { during the lesson. } \\
\text { For an ideal lesson, ITT ratio } \\
\text { should be slightly equal to DTT } \\
\text { ratio. }\end{array}$ & $\begin{array}{l}\text { The tallies of the first four categories are added } \\
\text { and divided by "N" to calculate the percentage. } \\
\text { ITT }=\frac{c_{1}+c_{2}+c_{3}+c_{4}}{N} \times 100\end{array}$ \\
\hline 6 & $D P T$ & $\begin{array}{l}\text { The DPT indicates how much } \\
\text { students initiate discussions } \\
\text { during the lesson. } \\
\text { For an ideal lesson, DPT ratio } \\
\text { should be slightly equal to IPT } \\
\text { ratio. }\end{array}$ & $\begin{array}{l}\text { The tallies of } 9^{\text {th }} \text { categories are divided by " } \mathrm{N} \text { " to } \\
\text { calculate the percentage. } \\
D P T=\frac{C_{9}}{N} x 100\end{array}$ \\
\hline 7 & $I P T$ & $\begin{array}{l}\text { IPT Ratio indicates how much } \\
\text { students respond during the } \\
\text { lesson. } \\
\text { For an ideal lesson, IPT ratio } \\
\text { should be slightly equal to DPT } \\
\text { ratio. }\end{array}$ & $\begin{array}{l}\text { The tallies of } 8^{\text {th }} \text { categories are divided by " } \mathrm{N} \text { " to } \\
\text { calculate the percentage. } \\
I P T=\frac{C_{8}}{N} \times 100\end{array}$ \\
\hline 8 & $I D$ & $\begin{array}{l}\text { The ID Ratio indicates whether } \\
\text { the teacher has an indirect } \\
\text { statement for each direct teacher } \\
\text { statement in his/her approach to } \\
\text { motivation, encouragement, and } \\
\text { control. } \\
\text { For an ideal lesson, an ID ratio } \\
\text { should be around } 100 \% \text { (ITT } \\
\text { equal to DTT). } \\
\text { If ID Ratio is more than } 100 \% \text {, the } \\
\text { teacher is said good for }\end{array}$ & $\begin{array}{l}\text { The tallies of first four categories are added and } \\
\text { divided by the sum of tallies of } 5^{\text {th }}, 6^{\text {th }} \text { and } 7^{\text {th }} \\
\text { categories to calculate the percentage. } \\
I D=\frac{c_{1}+c_{2}+c_{3}+c_{4}}{c_{5}+c_{6}+c_{7}} \times 100 \\
\text { ID ratio can be also calculated from ITT and } \\
\text { DTT ratios: } \\
I D=\frac{I T T}{D T T} \times 100\end{array}$ \\
\hline
\end{tabular}


African Journal of Educational Studies in Mathematics and Sciences Vol. 15, No. 2. 2019

\begin{tabular}{|c|c|c|c|c|}
\hline $\mathbf{S} / \mathbf{N}$ & Ratio & \multicolumn{2}{|c|}{$\begin{array}{l}\text { Description } \\
\text { motivating students. If ID Ratio is } \\
\text { less than } 100 \text {, the teacher is } \\
\text { emphasizing more on } 5^{\text {th }}, 6^{\text {th }} \& 7^{\text {th }} \\
\text { categories }\end{array}$} & Formula \\
\hline 9 & $T Q$ & \multicolumn{2}{|c|}{$\begin{array}{l}\text { The TQ Ratio measures the } \\
\text { teacher's tendency to use } \\
\text { questions rather than a lecture in } \\
\text { the more content-oriented parts of } \\
\text { the lesson. } \\
\text { The normal TQ value should be } \\
\text { higher than } 26 \%\end{array}$} & $\begin{array}{l}\text { It is calculated by multiplying the category } 4 \\
\text { frequency by } 100 \text { and dividing by the sum of } \\
\text { categories } 4 \text { and } 5 \text {. } \\
T Q=\frac{c_{4}}{c_{4}+c_{5}} \times 100\end{array}$ \\
\hline \multicolumn{5}{|c|}{ Sources: Sandefur et al.(1969), Flanders (1970), Evans (1970) and Wragg (2005) } \\
\hline \multicolumn{5}{|c|}{$\begin{array}{l}\text { Concerning the observed lessons and each teacher was free to choose a topic fror } \\
\text { which might not disturb their normal teaching and schemes of work. }\end{array}$} \\
\hline \multicolumn{5}{|c|}{ Table 3 Indicators for characterisation of teaching approaches. Source: Authors } \\
\hline \multicolumn{3}{|c|}{ Characteristics } & \multicolumn{2}{|l|}{ Indicators } \\
\hline \multicolumn{3}{|c|}{$\begin{array}{l}\text { The teacher's role } \\
\text { in the learning }\end{array}$} & \multicolumn{2}{|c|}{$\begin{array}{l}\text { ITT \& DTT ratios compared (teachers' initiation and the teachers' response } \\
\text { frequencies): if a teachers' initiate more than he responds, he is “information } \\
\text { giver" } \\
\text { ID ratio: For an ideal lesson, an ID ratio should be } 100 \% \text {, meaning ITT should be } \\
\text { equal to DTT. In addition, the DTT and DPT (teachers' initiation and the pupils' } \\
\text { initiation frequencies) compared to provide information on who initiates the } \\
\text { content to be taught } \\
\text { TT, PT \& SC ratios compared shows who is dominating the classroom } \\
\text { interaction }\end{array}$} \\
\hline \multicolumn{3}{|c|}{$\begin{array}{l}\text { The learners' } \\
\text { responsibility for } \\
\text { learning and } \\
\text { encouragement }\end{array}$} & \multicolumn{2}{|c|}{$\begin{array}{l}\text { PT ratio reveals the pupils' activities (learners' participation/involvement) in the } \\
\text { lesson. Responsive teacher talk is more indirect, tends to share authority, and } \\
\text { expands pupil participation } \\
\text { IPT \& DPT ratios compared shows the pupils' involvement in the lesson } \\
\text { ID ratio value to be } 100 \% \text {, indicator of teachers' or students' actions for } \\
\text { encouraging or restricting students' participation. }\end{array}$} \\
\hline
\end{tabular}

\section{Results from the FIACS}

Table 4 and Figure 1 show the overview of frequencies of the classroom verbal interaction in the six SET videotaped lessons. 
Teachers' role and learners' responsibility in teaching and learning science and elementary technology in Rwanda

Table $4 \quad$ Frequencies of the ten interaction categories in six lessons

\begin{tabular}{|c|c|c|c|c|c|c|c|c|c|c|}
\hline \multirow{3}{*}{ Categories } & \multicolumn{7}{|c|}{ Teacher talk } & \multicolumn{2}{|c|}{ Pupil talk } & \multirow{3}{*}{ 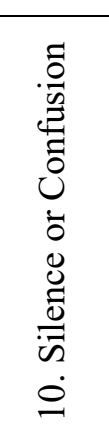 } \\
\hline & \multicolumn{4}{|c|}{ Response } & \multicolumn{3}{|c|}{ Initiation } & \multirow[b]{2}{*}{ 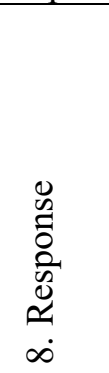 } & \multirow[b]{2}{*}{ 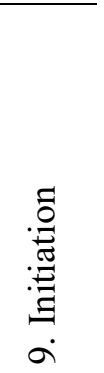 } & \\
\hline & 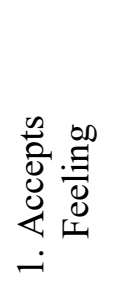 & 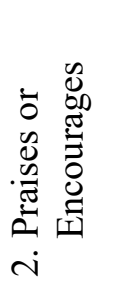 & 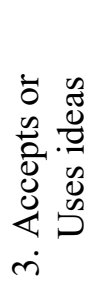 & 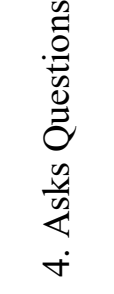 & 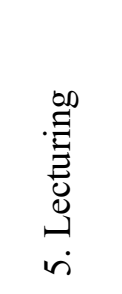 & 总 & 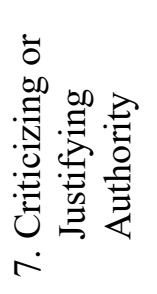 & & & \\
\hline Lesson 1 & 0.35 & 0.35 & 1.41 & 6.21 & 26.00 & 12.18 & 0.70 & 4.92 & 0.00 & 47.89 \\
\hline Lesson 2 & 0.00 & 0.08 & 1.66 & 8.94 & 40.31 & 2.32 & 1.16 & 13.41 & 0.58 & 31.54 \\
\hline Lesson 3 & 0.00 & 0.42 & 2.50 & 8.60 & 20.22 & 6.32 & 0.81 & 10.22 & 0.00 & 50.07 \\
\hline Lesson 4 & 0.00 & 0.00 & 4.53 & 7.47 & 34.67 & 2.93 & 0.00 & 10.40 & 0.00 & 40.00 \\
\hline Lesson 5 & 0.00 & 4.85 & 4.27 & 12.43 & 41.17 & 14.76 & 1.75 & 8.16 & 0.00 & 12.62 \\
\hline Lesson 6 & 0.00 & 0.00 & 4.31 & 17.80 & 42.29 & 5.22 & 0.11 & 13.61 & 0.00 & 16.67 \\
\hline Average & 0.06 & 0.89 & 2.75 & 10.15 & 32.71 & 6.76 & 0.79 & 10.47 & 0.13 & 35.29 \\
\hline
\end{tabular}

Considering the average of all the six analysed lessons, two categories of verbal interaction are the most frequent: Teacher Lecturing (average of 32.71\%) and Silence or confusion (35.29\%). Also, it was found that four categories have a very low frequency (below 1\%): Teacher Accepts Feeling, Teacher Praises or Encourages, Teacher Criticizing or Justifying Authority and Pupil Talk Initiation. 
African Journal of Educational Studies in Mathematics and Sciences Vol. 15, No. 2. 2019

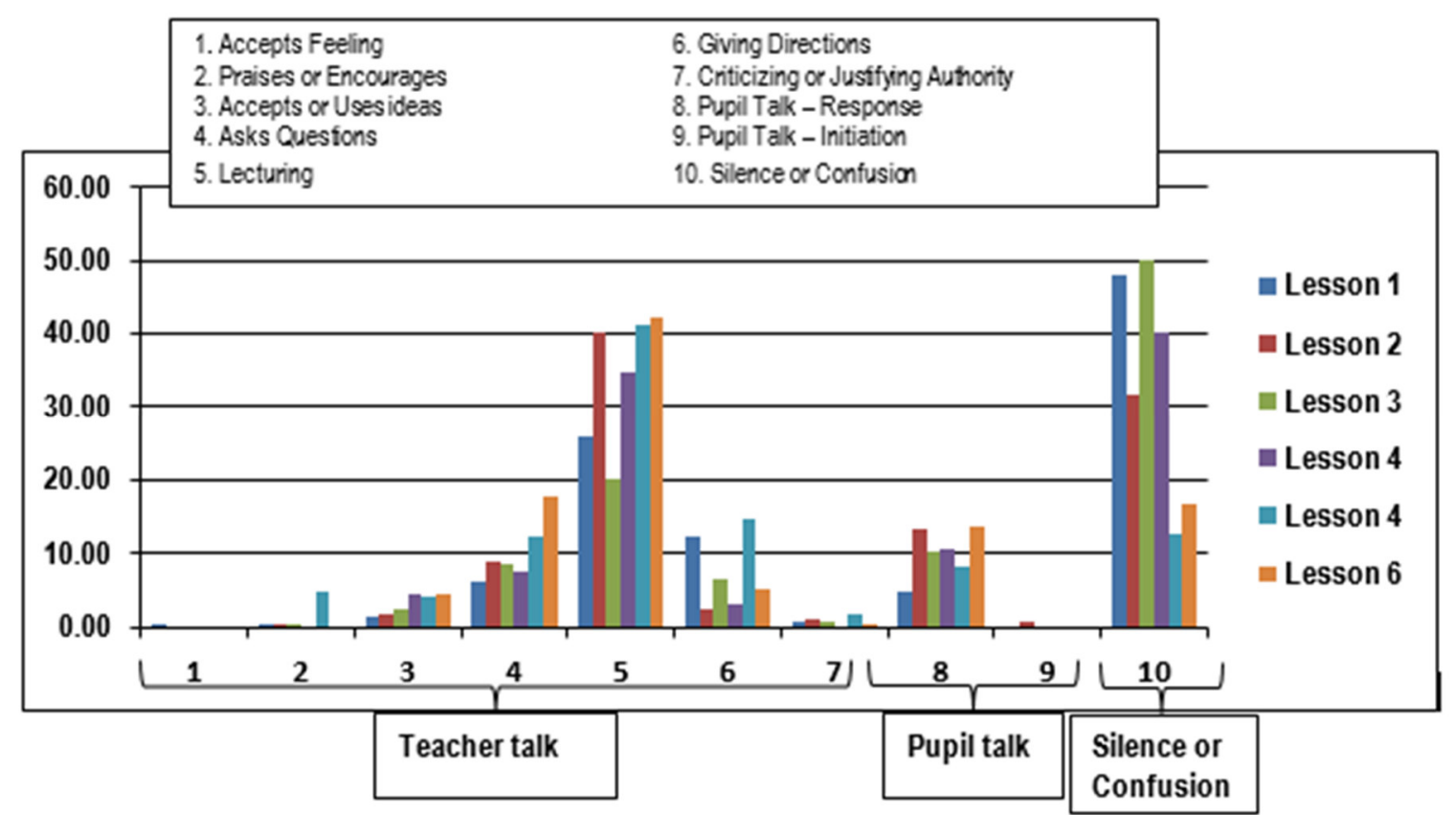

Figure 1 Frequencies of verbal interaction categories in six lessons

The following ratios (Table 5) have helped us to clarify the teachers' and pupils' behaviours in classrooms, and then determine the characteristics of teaching approaches.

Table 5 Calculated ratios from Flanders interaction analysis categories system (FIACS)

\begin{tabular}{|c|c|c|c|c|c|c|c|c|}
\hline & & $\begin{array}{c}\text { Lesson } \\
1\end{array}$ & $\begin{array}{c}\text { Lesson } \\
2\end{array}$ & $\begin{array}{c}\text { Lesson } \\
3\end{array}$ & $\begin{array}{c}\text { Lesson } \\
4\end{array}$ & $\begin{array}{c}\text { Lesson } \\
5\end{array}$ & $\begin{array}{c}\text { Lesson } \\
6\end{array}$ & $\begin{array}{c}\text { Averag } \\
\text { e }\end{array}$ \\
\hline TT & Teacher Talk & 47.19 & 54.47 & 39.71 & 49.60 & 79.22 & 69.73 & 54.10 \\
\hline PT & Pupil Talk & 4.92 & 13.99 & 10.22 & 10.40 & 8.16 & 13.61 & 10.61 \\
\hline $\mathrm{SC}$ & Silence or Confusion & 47.89 & 31.54 & 50.07 & 40.00 & 12.62 & 16.67 & 35.29 \\
\hline DTT & Direct Teacher Talk & 38.88 & 43.79 & 27.35 & 37.60 & 57.67 & 47.62 & 40.26 \\
\hline ITT & Indirect Teacher Talk & 8.31 & 10.68 & 12.35 & 12.00 & 21.55 & 22.11 & 13.84 \\
\hline DPT & Direct Pupil Talk & 0.00 & 0.58 & 0.00 & 0.00 & 0.00 & 0.00 & 0.13 \\
\hline IPT & Indirect Pupil Talk & 4.92 & 13.41 & 10.22 & 10.40 & 8.16 & 13.61 & 10.47 \\
\hline ID & Indirect and Direct & 21.39 & 24.39 & 45.16 & 31.91 & 37.37 & 46.43 & 34.39 \\
\hline TQ & Teacher's Question & 19.27 & 18.15 & 29.85 & 17.72 & 23.19 & 29.62 & 23.67 \\
\hline
\end{tabular}

In order to explain the meaning of each ratio related to the findings from the FIACS analysis from six analysed lessons, individually or not, the sections below will treat those ratios. 
Teachers' role and learners' responsibility in teaching and learning science and elementary technology in Rwanda

\section{J.C Nzeyimana \& K. Ndihokubwayo}

\section{Teacher Talk, Pupil's Talk, and Silence or Confusion ratios}

In the six lessons analysed, the "Teacher Talk", "Pupil's Talk" and "Silence or Confusion" ratios show us how much (the percentage time) the teacher talks, the pupils talk, and time spent in pauses, silence, and confusion. There are some similarities on the verbal interaction in the six lessons: very low percentages times of pupil talk compared to the time spend by the teacher in talking or compared to the times spend during in pauses, silence, and confusion. As shown in Table 5, the average values of "Teacher Talk", "Pupil's Talk" and "Silence or Confusion" ratios are respectively $54.10 \% ; 10.61 \%$ and $35.29 \%$.

The above ratios (TT, PT \& SC) are indicators of how much pupils (and teachers) had access to content taught, how much pupils were participating in a lesson and how much confusion or silence was observed in the lessons.

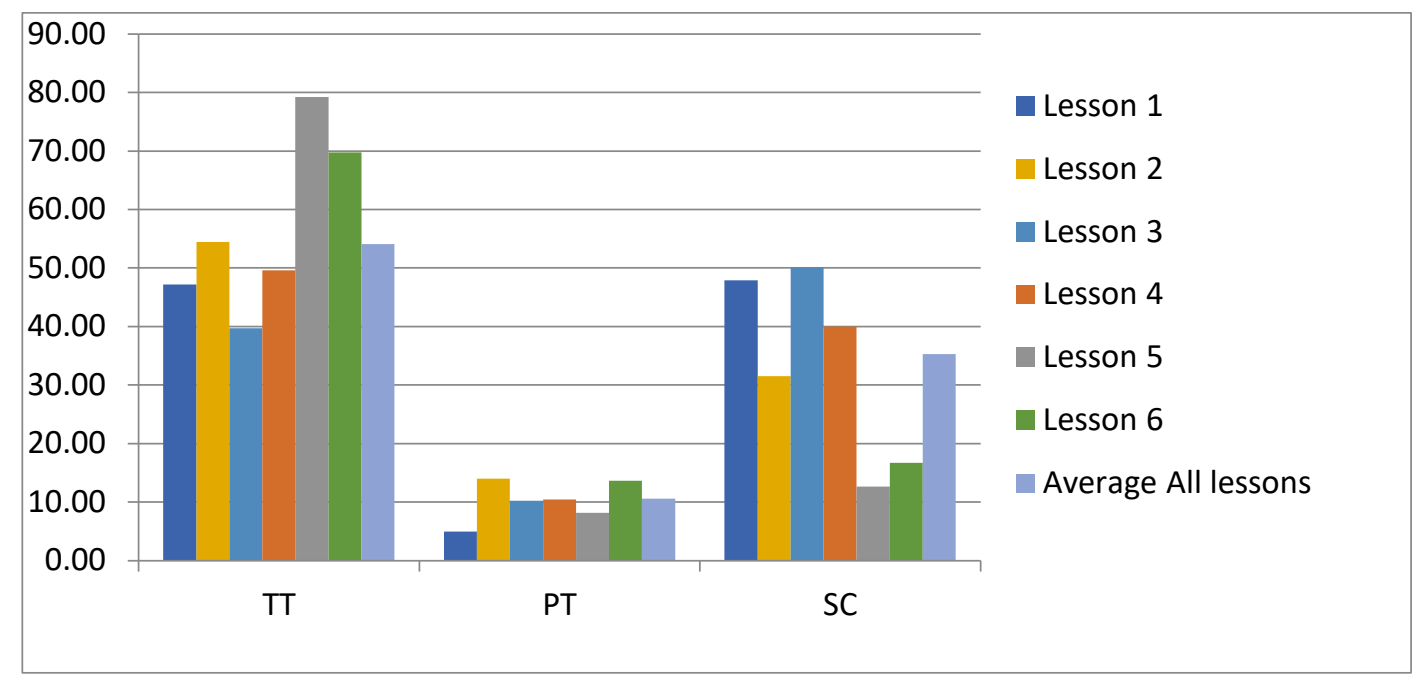

Figure 2

TT, PT and SC compared

Indirect Teacher Talk, Direct Teacher Talk, Indirect Pupil Talk, and Direct Pupil Talk ratios

In the classroom interaction analysis, the ratios "Indirect Teacher Talk" (ITT) also called "Teacher Talk Response", "Direct Teacher Talk" (DTT) also called "Teacher Talk Initiation", "Indirect Pupil Talk" (IPT) also called "Pupil Talk Response" and "Direct Pupil Talk" (DPT) also called "Pupil Talk Initiation" is indicators of pupils' participation and involvement in the lesson. The ITT Ratio indicates the how much the teacher responds to pupils' ideas during the lesson; the DTT indicates the teacher's actions restricting pupil participation; the IPT Ratio indicates the how much pupils respond during the lesson and the DPT indicates how much they initiate discussions during the lesson.

The above four ratios have a lot of information concerning the characterisation of teaching approaches. The Teacher Talk Response (ITT) and Teacher Talk Initiation (DTT) ratios compared reveal the relative balance between responding and initiating within teacher talk. From the average of ratios calculated based on six analysed lessons (Figure 3 and Table 5), DTT (40.26\%) is much 
higher than ITT (13.84\%), which is an indicator of how much teachers were directive, which tends to support the use of teacher authority, and restricts pupils participation (Evans, 1970).

On the pupils' side, although they had a little participation time in the six lessons, they were much more responding than initiating. The Pupil Talk Initiation (DPT) ratio was found very low (0.13\%): their initiation times were found only in the lesson 2, and all other five lessons didn't know any pupils' initiation times. The Pupil Talk Response (IPT) ratio is also very low (10.47\%) compared to the Teacher Talk Initiation (DTT) with the average frequency of $40.26 \%$, indicator that for each teachers' initiation, there was no equivalent pupils' response.

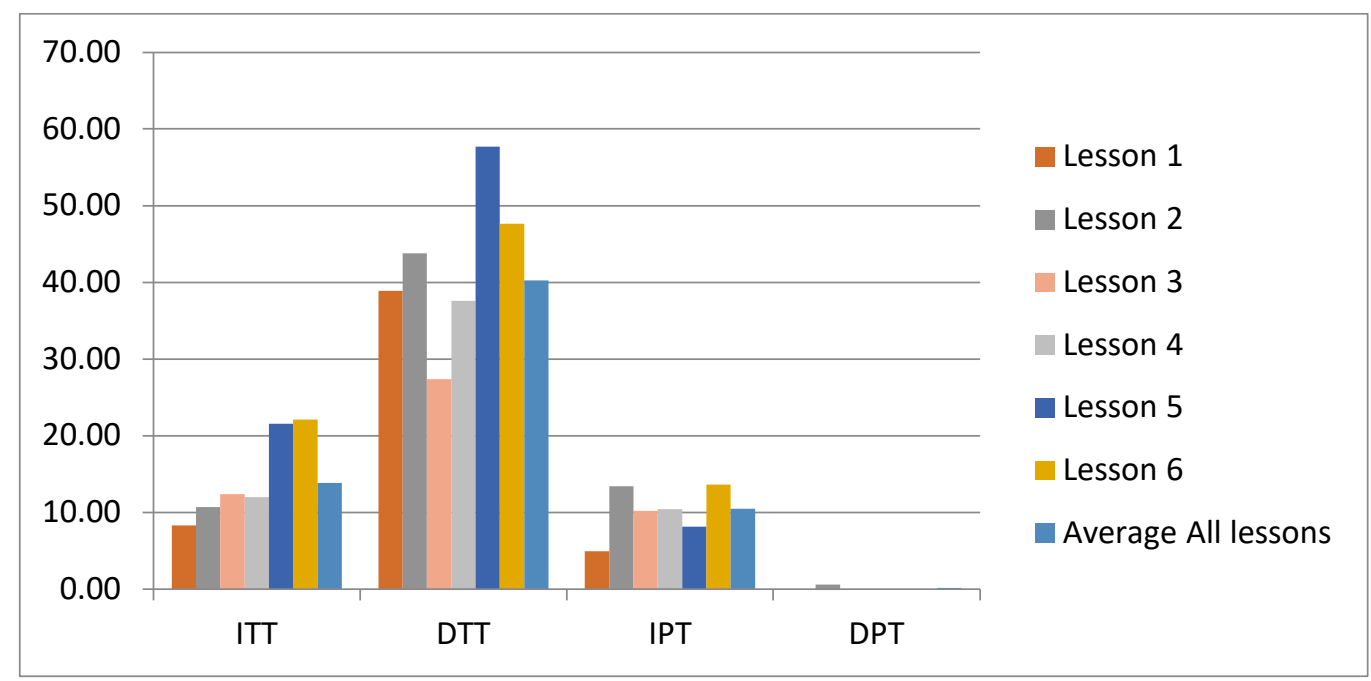

Figure $3 \quad$ ITT, DTT, IPT and DPT ratios compared

\section{Indirect and Direct Ratio}

By analysing the classroom interaction, it was found that the average ID ratio $(34.39 \%)$ was very low compared to the standard value of an ideal lesson. In fact, for an ideal lesson, an ID ratio should be $100 \%$ for a teacher who is said "good" for motivating learners. This means that for ID ratio to be $100 \%$, the Teacher Talk Response - ITT (calculated from categories 1, 2, 3 and 4) and Teacher Talk Initiation - DTT (calculated from categories 5, 6 and 7) should be equal (Table 2).

The ID Ratio indicates whether the teacher has an indirect statement for each direct teacher statement or to determine whether a teacher is indirect or direct in his approach to motivation, encouragement, and control. For the six analysed lessons, none of them had ID ratio values close to $100 \%$, indicator of an ideal lesson. This means that all analysed lessons were not good for motivating students and that the teachers were more initiating (lecturing, giving directions and criticizing or justifying authority) than responding (accepting feelings, praising/encouraging, accepting or using ideas of students and asking questions).

The ID ratio has helped us to get information on the instructor's role and on learners' encouragement and on types of the relation existing between teachers and learners. 
Teachers' role and learners' responsibility in teaching and learning science and elementary technology in Rwanda

J.C Nzeyimana \& K. Ndihokubwayo

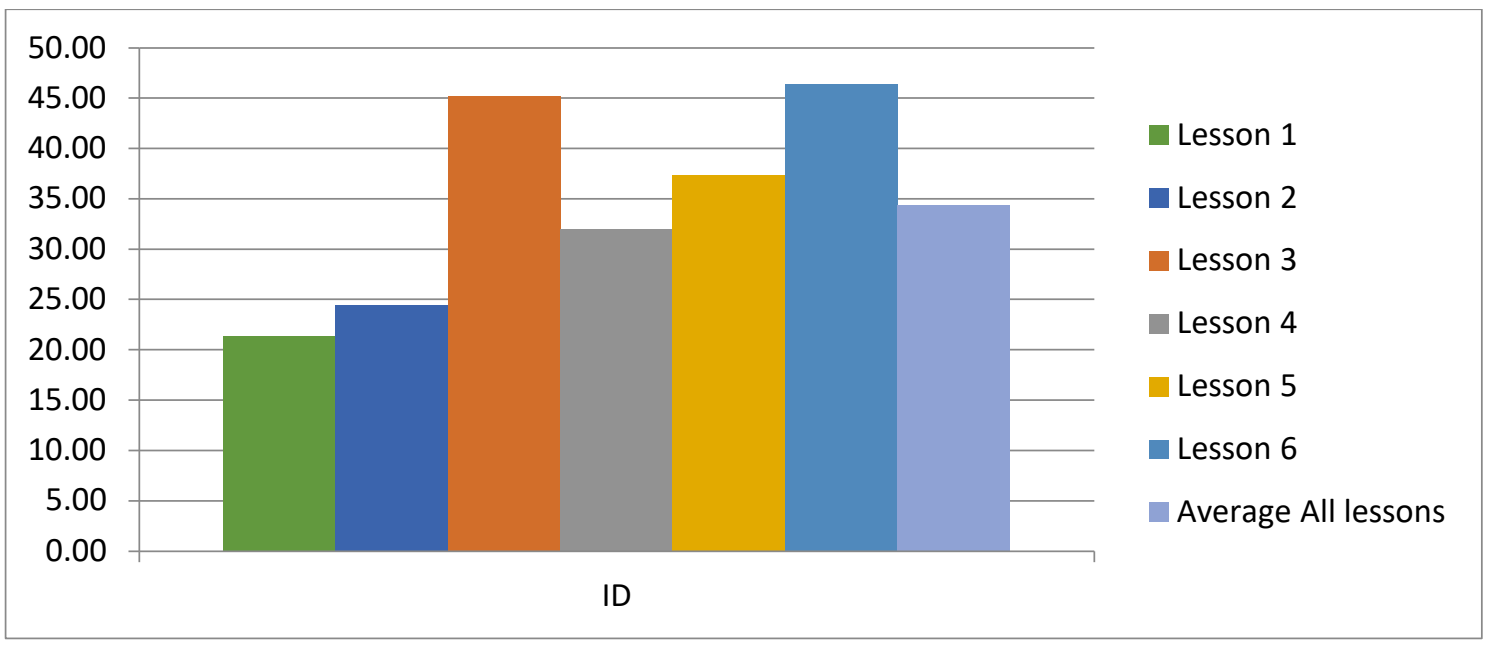

Figure 4 Indirect and Direct Ratio in Six Lessons

\section{Results Presentation and Discussions}

In order to determine the teachers' role and learners' responsibility in teaching and learning "Science and Elementary Technology" lessons in Primary schools of Kayonza District, in Rwanda, the presents study answered the following questions:

\section{Research Question 1: What is the instructor's role in learning activities?}

For a good learner-centred lesson, teachers are expected to be a guide, coach or/and facilitator of learning [Kisangi (2006), Di Napoli (2004), Weimer (2002), Huba \& Freed (2000); Attard, Di Ioio, Geven, \& Santa (2010); Allen (2004); Anderson et al. (2001); Kolb (1981) Westwood (2008) and Siddiquee \& Ikeda (2013b)]. In the six SET analysed lessons from Kayonza District, using FIACS analysis (Table 5, Figure 3 and Figure 4), for average ratio values, it was found that: The Teacher Talk Initiation ratio - DTT (40.26\%) is much higher than Teacher Talk Response ratio ITT (13.84\%). All teachers are found more initiating (DTT) than responding (ITT). This is an indicator that the role of the teachers was found to be "information givers".

The Indirect and Direct ratio - ID (34.39\%) for all the six lessons is very low compared to the standard ID value (100\%). A very low ID ratio reveals that there is a big difference between the teacher's direct statement and his/her indirect statement. For an ideal lesson, ID ratio should be around $100 \%$. This means that the direct - initiation statements $\left(5^{\text {th }}, 6^{\text {th }} \& 7^{\text {th }}\right.$ categories $)$ and the indirect - response statements $\left(1^{\text {st }}, 2^{\text {nd }}, 3^{\text {rd }} \& 4^{\text {th }}\right.$ categories $)$ should be slightly equal. Since the Teacher Talk Initiation ratio - DTT (40.26\%) and the Teacher Talk Response ratio - ITT (13.84\%) compared for all the six lessons shows a very high value of teachers' initiation $\left(5^{\text {th }}, 6^{\text {th }} \& 7^{\text {th }}\right.$ categories) and a very low value of teachers' response statements $\left(1^{\text {st }}, 2^{\text {nd }}, 3^{\text {rd }} \& 4^{\text {th }}\right.$ categories $)$. This is an indicator that the teachers' facilitation to learning was very low. The high value of DTT ratio also indicates a very high teacher's involvement in the classroom interaction, proof that they were deciding alone on the content taught in the classrooms. This is because the pupils didn't make any initiating statement (low DPT ratio value). 
The Teacher Talk ratio - TT $(54.10 \%)$ shows that for all the lessons, the teacher-talking times are much higher than the pupils' talking times - PT ratio $(10.61 \%)$ and silence or confusion times $\mathrm{SC}$ ratio $(35.29 \%)$. This shows how much teachers were talking in the classrooms much more than the pupils did. Teachers were in fact, dominating all the classroom interactions.

The three observations above answer the first research question: the instructors' role in the learning was found information giver. Teachers had low facilitation to learning and were deciding alone on the content to be taught. These are some of the characteristics of a teacher-centred lesson.

Research Question 2: What is the pupils' responsibility for learning and what is their encouragement?

Teachers, as well as learners, have an important role to play in the process of learning. For a learner-centred learning, learners should have intrinsic encouragement for learning, be actively involved in their learning, learn as individualities collaborating in small groups under teacher's supervision, and teachers should be helping them to take initiatives in their learning [Kisangi (2006), Di Napoli (2004), Weimer (2002), Huba \& Freed (2000); Attard, Di Ioio, Geven, \& Santa (2010); Allen (2004); Anderson et al. (2001); Kolb (1981) Westwood (2008) and Siddiquee \& Ikeda (2013b)].

By using FIACS analysis (Table 5, Figure 2, Figure 3 and Figure 4), the present study has analysed some ratios like PT (Pupil Talk), IPT (Pupil Talk Response), DPT (Pupil Talk Initiation) and ITT (Teacher Talk Response). For the average ratio values of six analysed lessons, it was found that: The average value of PT ratio for six lessons is very low (10.61\%) compared to teacher talking times - TT ratio (54.10\%); proof of low pupils' participation in the classrooms. With such pupils' participation ratio in the six analysed lessons (10.61\%), mainly categorized in "Pupil Talk Response" category $(10.47 \%)$, it is a net indicator of low students' participation and very low pupils' initiatives in their learning.

The average values of the Pupil Talk Response - IPT and Pupil Talk Initiation - DPT ratios are respectively $10.47 \%$ and $0.13 \%$, where it was observed a big gap between pupils' initiation and response frequencies. The comparison of the above ratios reveals that pupils have only answered the questions in the lessons, and didn't give any new original ideas (lack of initiatives in classroom interaction).

The average values of the Teacher Talk Response - ITT and Teacher Talk Initiation - DTT was found respectively $13.84 \%$ and $40.26 \%$. It results in an ID ratio of $34.39 \%$, very low compared to the standard ID value, $100 \%$. Since the ID ratio is calculated based on ITT and DTT ratios (Table $2)$, and since ITT ratio shows the teacher's attention to ideas expressed by students $\left(1^{\text {st }}, 2^{\text {nd }}, 3^{\text {rd }} \&\right.$ $4^{\text {th }}$ categories -continuing use of acceptance and praise, constructive reaction to pupil feeling, and clarifying, accepting and developing pupil ideas and asking questions) and the DTT ratio shows the teacher's actions restricting pupils participation (lecturing, giving directions and criticizing or justifying authority); the three ratios are indicator to pupils' encouragement for learning by the teachers. The ID ratio value of $34.39 \%$ is much lower to let us qualify the teachers' approach not motivating/ encouraging learners in their learning.

From the above discussions, the results are far from the expectations related to a learner-centred situation: low pupils' participation, lacking initiatives from pupils and teachers not motivating/encouraging pupils. The learners were found passive in the classroom interaction, and only responding to teachers' questions. 
Teachers' role and learners' responsibility in teaching and learning science and elementary technology in Rwanda

J.C Nzeyimana \& K. Ndihokubwayo

\section{Conclusion}

This research endeavoured to determine the characteristics of teaching approaches used in teaching "Science and Elementary Technology" lessons in Primary Schools of Kayonza District, in Rwanda by analysing actual SET lessons in primary schools. The present research has proved that all the above-mentioned aspects are lacking: The instructors' role in the learning was found information giver. Teachers had low facilitation to learning and were deciding alone on the content to be taught. Concerning the pupils' responsibility and their encouragement for learning, it was found that the results are far from the expectations related to a learner-centred situation: low pupils' participation, lacking of initiatives from pupils and teachers not motivating/encouraging them. The pupils were found passive in the classroom interaction, and only responding to teachers' questions. This study recommends teachers to reflect back on their teaching activities, calculate the time spend in order to spare it and give learners opportunities to express themselves. It is further recommended to researchers to carry out a related research comparing these results to the new 2015 competencebased curriculum. Will it change something?

\section{References}

Adkisson, C. \& McCoy, L.P. (2006). A study of teachers' perceptions of high school mathematics instructional methods. In L.P. McCoy (Ed.), Studies in teaching 2006: Research Digest (pp.1-6). Winston-Salem, NC: Wake Forest University

Allen, M. J. (2004). Assessing Academic Programs in Higher Education. Bolton, MA: Anker Publishing Company.

Anderson, L. W., Krathwohl, D. R., Airasian, P. W., Cruikshank, K. A., Mayer, R. E., Pintrich, P. R., . . . Wittrock, M. C. (2001). A Taxonomy for Learning, Teaching, and Assessing: A Revision of Bloom's Taxonomy of Educational Objectives (Abridged ed.). New York: Addison Wesley Longman, Inc.

Attard, A., Di Ioio, E., Geven, K., \& Santa, R. (2010). Student Centered Learning. An Insight into Theory and Practice (A. Attard Ed.). Bucharest: Education International \& European students' Union.

Bales, Robert Freed (1999) Social Interaction Systems: Theory and Measurement. New Brunswick, N.J. ; London : Transaction.

Di Napoli, R. (2004). What is Student-centred Learning? In E. I. Centre (Ed.), (pp. 7). London, UK: Educational Initiative Centre, University of Westminster.

Earnest, J. (2006). Science Education Reform in a Transitional Society: The Case of Rwanda. In J. Earnest \& D. Treagust (Eds.), Education Rebuilding in Societies in Transition: International Perspectives (pp. 129-145). Rotterdam, Netherlands: Sense Publishers.

Ertmer, P. A., \& Simons, K. D. (2006). Jumping the PBL Implementation Hurdle: Supporting the Efforts of K-12 Teachers. Interdisciplinary Journal of Problem-based Learning, 1(1), 4054. 
African Journal of Educational Studies in Mathematics and Sciences Vol. 15, No. 2. 2019

Evans, T. P. (1970). Flanders System of Interaction Analysis and ScienceTeacher Effectiveness. Paper presented at the Forty-Third Annual Meeting of the National Association for Research in Science Teaching, Minneapolis, Minnesota.

Flanders, N. A. (1970). Analyzing Teaching Behavior. United States of America: Addison-Wesley Publishing Company.

Huba, M. E., \& Freed, J. E. (2000). Learner-Centered Assessment on College Campuses. Shifting the Focus from Teaching to Learning (A. a. Bacon Ed.). Boston, MA: Pearson.

Jarvis, P. (2006). Teaching styles and teaching methods. In P. Jarvis (Ed.), The Theory and Practice of Teaching (2nd ed., pp. 273). New York, NY Routledge.

Kisangi, A. K. (2006). Exploring Student-Centered Learning of Biology in Japanese High Schools: Considering its Adaptability to the Kenyan Situation. (Masters Degree), Hiroshima University, Unpublished Thesis.

Kolb, D. A. (1981). Learning Styles and Disciplinary Differences. In C. A. W. (Ed.), The Modern American College (pp. 232-255). San Francisco: Jossey-Bass.

Ministry of Education. (2006). Education Sector Strategic Plan 2006 - 2010. Kigali.

Ministry of Education. (2010a). Education Sector Strategic Plan 2010-2015. Kigali, Rwanda.

Ministry of Primary and Secondary Education. (1996). Primary School Sciences and Elementary Technology Programme. Kigali, Rwanda: Direction of Studies and Pedagogical Research.

Rwanda Education Board. (2012). Training manual for Revised Science and Elementary Technology for Upper Primary Curriculum. Kigali, Rwanda: REB.

Sandefur, J. T., Pankratz, R., \& Sullivan, J. (1969). Teaching Experience as a Modifier of Teaching Behavior (pp. 47). Emporia, Kansas Kansas State Teachers College.

Savery, J. R. (2006). Overview of Problem-based Learning: Definitions and Distinctions. Interdisciplinary Journal of Problem-based Learning, 1(1), 9-20.

Siddiquee, M. N.-E.-A., \& Ikeda, H. (2013a). Science Talk in the Secondary Classrooms: Analysis of Teachers' Feedback. European Scientific Journal, 9(22), 87-104.

Siddiquee, M. N.-E.-A., \& Ikeda, H. (2013b). Science Teachers' Beliefs on Teaching and Learning at Secondary Schools in Bangladesh. GSE Journal of Education, 37-63.

Trigwell K. (2006). Phenomenography: An Approach to Research into Geography Education. Journal of Geography in Higher Education Volume 30, 2006 - Issue 2

Weimer, M. (2002). Learner-Centered Teaching: Five Key Changes to Practice. San Francisco: Jossey Bass.

Westwood, P. S. (2008). What teachers need to know about teaching methods (C. Glascodine Ed.). Victoria, Australia: Camberwell, Vic., ACER Press. 
Teachers' role and learners' responsibility in teaching and learning science and elementary technology in Rwanda

J.C Nzeyimana \& K. Ndihokubwayo

Wragg, E. C. (2005). The Art and Science of Teaching and Learning. The selected works of Ted Wragg. New York: Taylor \& Francis e-Library. 